\title{
Long-term Effects of Fire on Cactus in the Southern Mixed Prairie of Texas
}

\author{
STEPHEN C. BUNTING, HENRY A. WRIGHT, AND LEON F. NEUENSCHWANDER
}

\section{Abstract}

Few brownspine pricklypear were immediately killed by the direct effects of fire. Most plants resprouted after burning in the spring, but mortality averaged $70 \%$ by the end of the fourth year after burning. Interactions of fire with insects and rodents caused most of the brownspine pricklypear mortality. Walkingstick cholla and tasajillo were more directly affected by fire than brownspine pricklypear. First-year mortality was 40 to $65 \%$, respectively; and fourth year mortality was 57 to $80 \%$. Mortalities of other minor species of cactus varied from 49 to $100 \%$.

The increase of cactus on grassland ranges, particularly in the Southwest, has been a problem for many years. During a 17-year period (1932-1949) in southern Arizona, jumping cholla (Opuntia fulgida) increased from 5 to 368 plants/ha, cane cholla $(O$. spinosior) increased from 14 to 785 plants/ha, and Engelmann pricklypear $(O$. engelmannii) increased from 0 to 74 plants/ha in a grazed area (Glendening 1952). On an ungrazed area, percentage increase for cane cholla and Engelmann pricklypear were similar to the increases on a grazed area over the same period of time (Glendening 1952). These data indicate that neither reduced grazing pressure nor increasd grass competition will prevent the increase of cacti density.

However, Cook (1942), working in the Central Great Plains with pricklypear $(O$. humifus $a$ ), observed that ranges with dense stands of grass also supported high populations of Melitera dentata, a cactus feeding moth, during years with aboveaverage precipitation. The cactus feeding moth was a major factor in reducing cactus density. Ranges in poor condition did not have high enough populations of moths to cause cactus mortality. Thus, reduced grazing pressure in combination with above-normal moisture can reduce the density of cacti, at least on the eastern edge of cacti ranges. Drouths favor cacti throughout their range (Cook 1942; Houston 1963), and fire and animal use are left as the primary factors to control their density (Humphrey 1958).

High densities of cactus plants can reduce forage production and utilization. Rea and Pieper (1973) found that controlling walkingstick cholla $(O$. imbricata) on blue grama (Bouteloua gracilis) range increased herbage production by $20 \%$ and utilization by $9 \%$. Bement (1968), however, was unable to show an increase in herbage production after control of plains pricklypear ( $O$. polyacantha).

\footnotetext{
Authors are assistant professor of range management, College of Forestry, Wildlife, and Range Sciences, University of Idaho, Moscow 83843 and Horn professor of range management, Texas Tech University, Lubbock, Texas 79409; and assistant professor of Forestry, College of Forestry, Wildlife, and Range Sciences, University of Idaho, Moscow 83843.

This research is a contribution of the College of Agricultural Sciences, Texas Tech University, Publication Number T-9-184.

Manuscript received February 16, 1978.
}

Cactus plants vary in their response to fire, depending on species, size, and how soon they are observed after a fire. In Arizona, Humphrey and Everson (1951) found that 1 year after a fire the densities of Englemann pricklypear, jumping cholla, and cane cholla had decreased 9,29 , and $7 \%$, respectively. However, Reynolds and Bohning (1956) reported that a prescribed fire reduced densities of barrel cactus (Ferocactus wislizeni) $67 \%$, jumping cholla $44 \%$, cane cholla $45 \%$ and Engelmann pricklypear $28 \%$ after 2 years. Similarly, Cable (1967) found that fire reduced densities of jumping cholla 63\%, cane cholla $45 \%$, and Engelmann pricklypear $32 \%$ by the second year after a fire. In Texas, mortality of brownspine pricklypear $(O$. phaeacantha) was $20 \%$ the year after burning and $68 \%$ after the second year (Heirman and Wright 1973). Thus, first year mortality is not an adequate indication of the effect of fire on cacti mortality.

Small cacti are more susceptible to fire damage than the taller plants (Dwyer and Pieper 1967; Heirman and Wright 1973). Density of walkingstick cholla less than $0.3 \mathrm{~m}$ tall was reduced $50 \%$, but larger plants were not severely damaged by fire (Dwyer and Pieper 1967). Hierman and Wright (1973) found that the mortality of walkingstick cholla less than $0.3 \mathrm{~m}$ tall was $81 \%$, and for those greater than $0.3 \mathrm{~m}$ tall, mortality was $45 \%$. They observed little difference in the mortality of large $(\geq 10$ pads) and small ( $<10$ pads) brownspine pricklypear.

The purpose of this study was to measure the long-term effect of fire and drought on three major cactus species-brownspine pricklypear, walkingstick cholla, and tasajillo $(O$. leptoc(ul/is)-and several less common species in West Texas.

\section{Study Area and Methods}

This study was conducted in Callahan, Garza, and Mitchell counties, Texas, which lie within the Southern Mixed Prairie. Topography of the Beckham Ranch, in Callahan County, is level to undulating with some areas dissected by steep canyons. The average precipitation is $66 \mathrm{~cm}$. The soil is a limestone-derived stony loam. The area is dominated by little bluestem (Schizachyrium scoparium), buffalograss (Buchloe dactyloides), sideoats grama (Bouteloua curtipendula), and Texas wintergrass (Stipa leucotricha). Several species of oak (Quercus sp.) and ashe juniper (Juniperus ashei) are interspersed with the grasses. The large juniper had been dozed before burning.

Study sites on the Dalby Ranch, in Garza County, were located on a level area dominated by tobosagrass (Hilaria mutica) and alkali sacaton (Sporobolus airoides) with an overstory of walkingstick cholla and honey mesquite (Prosopis glandulosa var. glandulosa) less than $1.2 \mathrm{~m}$ tall. The average annual precipitation is $48 \mathrm{~cm}$ and the soil 
is a heavy clay vertisol.

Study sites on the Renderbrook-Spade Ranch in Mitchell County were located on a level to undulating tobosagrass-mesquite community. Untreated mesquite are medium-sized trees ( 3 to $4 \mathrm{~m}$ ), but had been sprayed with 2,4,5-T[2,4,5,-trichlorophenoxy) acetic acid] 6 years before the first prescribed fire. The average annual precipitation is $50 \mathrm{~cm}$ and the soil is a clay vertisol.

Brownspine pricklypear were permanently marked with iron stakes on prescribed spring burns on the Beckham Ranch in 1971, and on the Renderbrook-Spade and Dalby Ranches in 1972 and 1974. Additional pricklypear plants had been marked on a wildfire that occurred on the Dalby Ranch in July, 1970. Tasajillo were permanently marked on the Renderbrook-Spade Ranch in 1973 and 1974. Walkingstick cholla were marked on two prescribed fires on the Dalby Ranch in the spring of 1973. Smaller numbers of less common cacti, devil's pincushion (Echinocactus terensis), Mammillaria gummitera, star cactus (Coryphantha vivipara), Echinocereus reichenbachii and Engelmann pricklypear were also marked. Mortality was based on a total of 600 brownspine pricklypear, 200 walkingstick cholla, 175 tasajillo, 79 devil's pincushion, 66 mammillaria gummitera, 10 star cactus, and 18 Echinocereus reichenbachii.

Brownspine pricklypear was divided into size classes by pad counts $(1-10,11-25$, and $>25)$ and cholla and tasajillo by height $(\leq 0.6 \mathrm{~m}$ and $>0.6 \mathrm{~m}$ tall). Mortality was recorded during July and December each year until December, 1976. Mortality was determined by the absence of living tissue above ground on permanently marked plants on each sampling date. Subsequent mortalities were accumulative for every species on each prescribed burn. An individual cactus plant might be recorded as "dead" on one date and then resprout and be recorded as "living" on a following date. This resulted in a decline in mortality for tasajillo during some years. Chi-square analysis was used to test for differences in mortality between burned and unburned treatments and between size classes of cacti plants.

\section{Results and Discussion}

\section{Brownspine Pricklypear}

Fire caused little immediate mortality of brownspine pricklypear. The plants were usually top-killed, but within a few weeks after the burn all had resprouted. Average mortality was only $20 \%$ at 6 months after the fire. By the end of the third year, however, mortality exceeded $70 \%$ (Fig. 1). After the third year, mortality of pricklypear increased about the same rate as it did for the unburned plants.

Mortality during the first 3 years apparently was caused primarily by fire weakening the plant and making it more susceptible to damage by insects, rodents, and rabbits. Insects entered the plant through fire-scarred tissue and spread to the young living pads, opening the plant to bacterial and fungal infections. Pads sprouting from burned plant tissue often lost their vascular connection to the root system because of insect damage and decay. Plants sprouting from the root crown survived for a longer period but many of these also died. Most of the plants that survived after 3 years, however, had sprouted from the root crown.

Young pads require several weeks before the spines are fully developed. During this time they are frequently browsed by lagomorphs and rodents. This is particularly important during the winter and dry summers when other green material is scarce. The mortality of both burned and control (unburned) plants increased during years when precipitation was below average. Over $50 \%$ of one set of control pricklypear plants located on a shortgrass site died during one drought year, probably because they were easily visible and eaten by lagomorphs and rodents. Only $8 \%$ of the control plants on tobosagrass sites died during this period. The taller grasses on these sites seem to provide
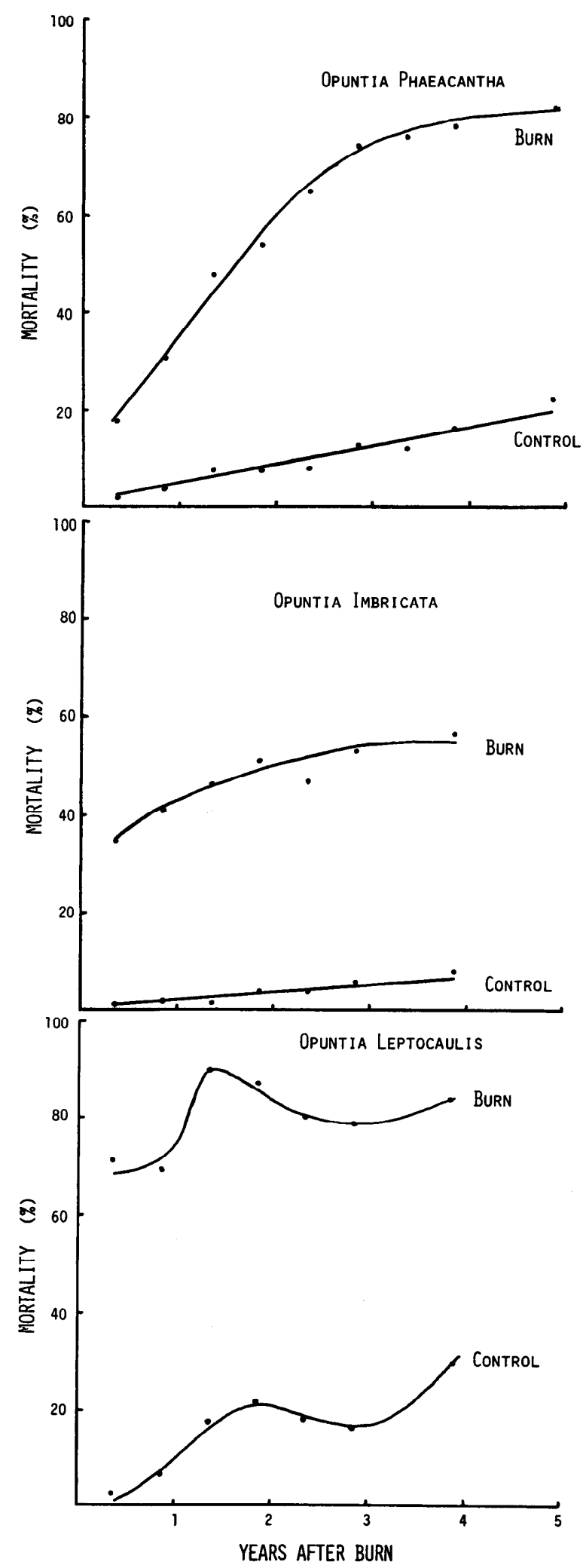

Fig. 1. Mortality of Opuntia phaeacantha, O. imbricata and $\mathrm{O}$. leptocaulis after prescribed burning in early spring. Mortality was caused by a combination of damage by fire, insects, and rodents.

more protection against browsing by small animals. Cactus plants growing in shortgrass (i.e. buffalograss), however, are less susceptible to fire-induced damage. Drought and droughtinduced browsing may be major factors in reducing prickly pear densities on shortgrass sites. 
Table 1. Percent mortality of different size classes of Opuntia phaeacantha in relation to years after a prescribed burn in tobosagrass $(6,000 \mathrm{~kg} / \mathrm{ha})$ in West Texas.

\begin{tabular}{lcc}
\hline \multirow{2}{*}{$\begin{array}{l}\text { Size class } \\
\text { (pads/plant) }\end{array}$} & \multicolumn{3}{c}{ Years after burn $^{1}$} \\
\cline { 2 - 3 } & 1 & 3 \\
\hline $1-10$ & $27 \mathrm{a}$ & $75 \mathrm{a}$ \\
$11-25$ & $20 \mathrm{~b}$ & $81 \mathrm{a}$ \\
$>25$ & $11 \mathrm{c}$ & $68 \mathrm{a}$ \\
\hline
\end{tabular}

${ }^{1}$ Numbers within a column followed by different letters are significantly different $(P<0.05)$.

At the end of the first year the small plants ( 1 to 10 pads) had a higher mortality than the large plants ( $>10$ pads), but by the end of 3 years there were no significant differences between the size classes of pricklypear (Table 1).
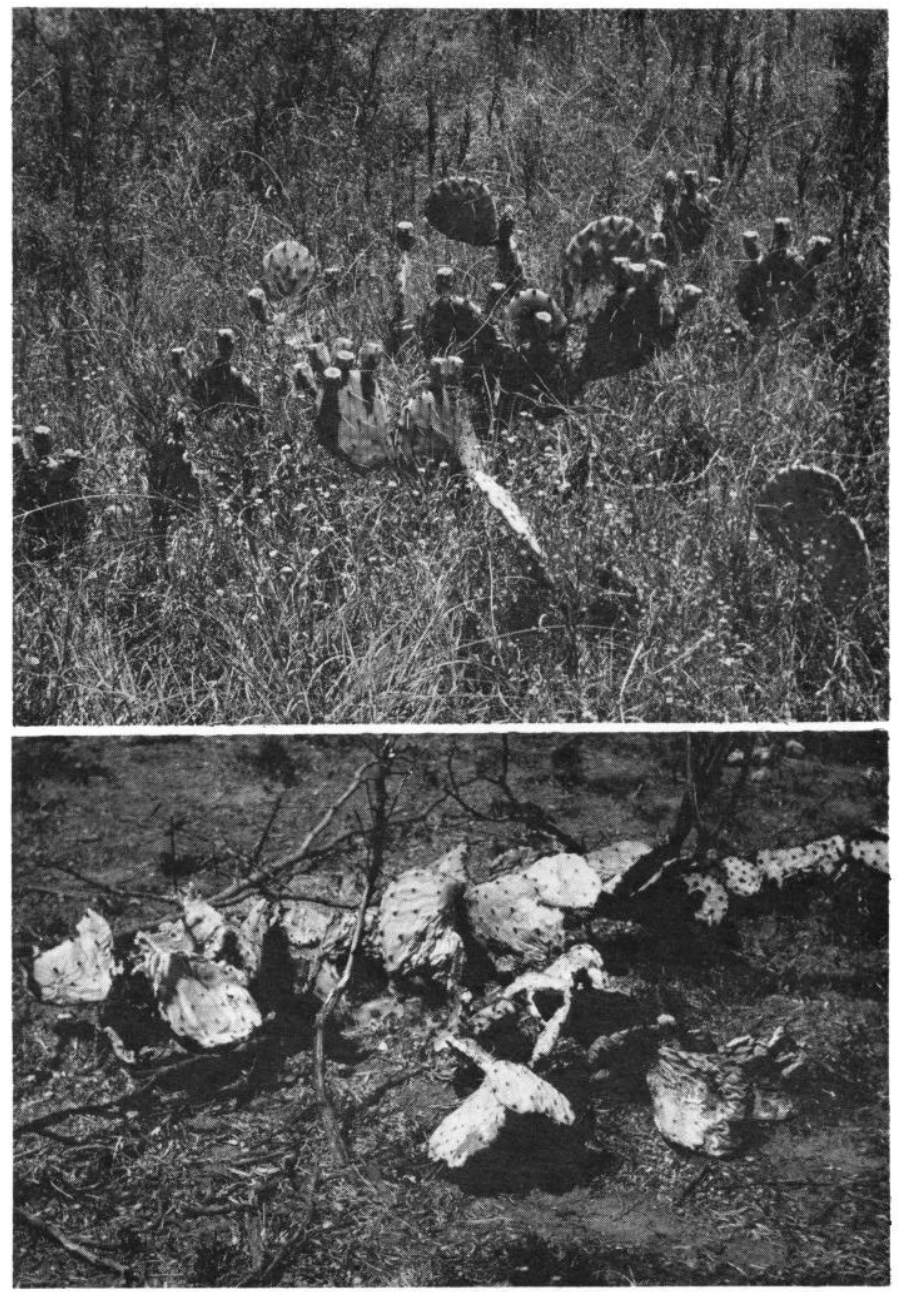

Fig. 2. Because of the dense fuel within the canopy of the brownspine pricklypear (top), most plants are top-killed by fire (bottom).

\section{Walkingstick Cholla}

Fire had a more direct effect on the mortality of walkingstick cholla than on brownspine pricklypear. At the end of the first year over $40 \%$ of the walkingstick cholla plants had died. Most of the plants that died were less than or equal to $0.6 \mathrm{~m}$ tall. Over $60 \%$ of the shorter plants died, whereas, only $16 \%$ of the plants greater than $0.6 \mathrm{~m}$ tall died. At the end of 3 years, mortalities were 73 and $27 \%$, respectively, for the short $(\leq 0.6 \mathrm{~m})$ and tall $(>0.6 \mathrm{~m})$ plants Table 2$)$; total mortality was $53 \%$. Beginning with the fourth year, mortality of burned and unburned plants

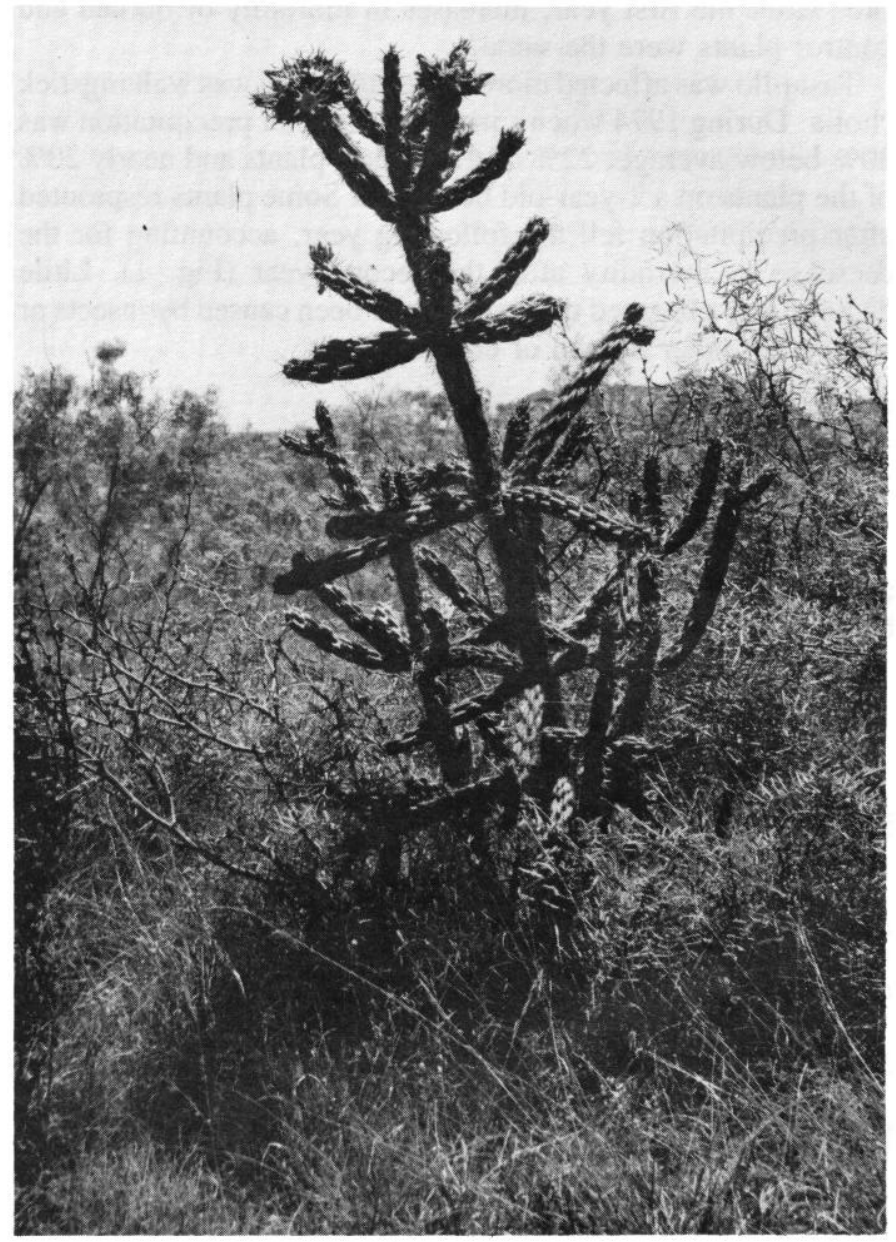

Fig. 3. Walkingstick cholla greater than $0.6 \mathrm{~m}$ tall suttered fire damage to only the lower branches, and mortality of these plants was significantly less than for the shorter plants.

increased at the same rate. In Arizona, Martin et al. (1974) reported that density of cholla may actually increase after fire as a result of joints falling from the plants and taking root. This was not observed with walkingstick cholla in West Texas.

Table 2. Percent mortality of different size classes of Opuntia imbricata in relation to years after a prescribed burn in tobosagrass $(6,000 \mathrm{~kg} / \mathrm{ha})$ in West Texas.

\begin{tabular}{lcc}
\hline \hline $\begin{array}{c}\text { Size class } \\
(\mathrm{cm})\end{array}$ & \multicolumn{3}{c}{ Years after burn $^{1}$} \\
\cline { 2 - 3 } & 1 & 3 \\
\hline$<61$ & $61 \mathrm{a}$ & $73 \mathrm{a}$ \\
$>61$ & $16 \mathrm{~b}$ & $27 \mathrm{~b}$ \\
\hline
\end{tabular}

${ }^{1}$ Numbers within a column followed by different letters are significantly different $(P<0.01)$

Neither drought nor the activity of rodents and insects appears to have as much effect on mortality of cholla as on pricklypear. The bases of some walkingstick cholla plants were stripped of the green epidermal tissue but most plants were able to recover. The woody interior may protect the vascular system of the plant. Mortality of control plants was about $2 \%$ year throughout the study.

\section{Tasajillo}

Tasajillo were highly susceptible to direct damage from fire. Many of the plants did not resprout after fire, and $65 \%$ of the plants were dead after the first year. Tasajillo, most of which were seldom greater than $0.6 \mathrm{~m}$ tall, were usually top-killed by 
fire. After the first year, increases in mortality of burned and control plants were the same.

Tasajillo was affected more by drought than was walkingstick cholla. During 1974 when spring and summer precipitation was $30 \%$ below average, $22 \%$ of the control plants and nearly $20 \%$ of the plants on a-2-year-old burn died. Some plants resprouted after precipitation fell the following year, accounting for the decrease in mortality after the second year (Fig. 1). Little damage was observed that might have been caused by insects or rodents to either burned or control plants.

\section{Other Cacti Species}

The numbers of several other species of cactus studied were small but some inferences on their response to fire are possible. Mortality of devil's pincushion occurred gradually after fire. They were also attacked by rodents and insects after the epidermis was damaged by heat, resulting in the growing center being eaten from many of the plants. After 3 years, mortality of devil's pincushion was over $40 \%$ (Table 3 ).

Table 3. Percent mortality of various cactus species in relation to years after a prescribed burn in tobosagrass $(6,000 \mathrm{~kg} / \mathrm{ha})$ in West Texas.

\begin{tabular}{lccccc} 
& \multirow{2}{*}{$\begin{array}{c}\text { Number of } \\
\text { Species }\end{array}$} & \multicolumn{4}{c}{ Years after burn } \\
\cline { 3 - 6 } & plants & 1 & 2 & 3 & 4 \\
\hline Echinocactus texensis & 79 & 17 & 30 & 44 & 49 \\
Mammillaria gummitera & 66 & 33 & 70 & 73 & 74 \\
Echinocereus reichenbachii & 18 & 17 & 89 & 94 & - \\
Conphantha vivipara & 10 & 100 & 100 & 100 & 100 \\
\hline
\end{tabular}

Mammillaria gummifera and Echinocereus reichenbachii plants were severely damaged by fire. At the end of the first year after burning, mortalities were 33 and $17 \%$ respectively. Two years later, mortalities were 71 and $89 \%$ and did not change appreciably thereafter. Most surviving plants were in areas with less than $1,000 \mathrm{~kg} / \mathrm{ha}$ of fine fuel. Star cactus was very susceptible to fire (Table 3 ). This may partially explain its rare occurrence except on rocky, lightly vegetated sites.

Engelmann pricklypear plants were not seriously injured by most of the grass fires. The center of the plants usually contained light grass cover due to small animal activity. This combined with its upright growth form resulted in only the peripheral pads of Engelmann pricklypear being damaged by fire. The average size of the plants was reduced, but most individuals survived. Plants less than $0.3 \mathrm{~m}$ tall and plants in areas with more than $6,000 \mathrm{~kg} / \mathrm{ha}$ of fine fuel reacted to fire much like brownspine pricklypear.

\section{Conclusions}

Prescribed burning effectively controlled the density of several species of cacti in West Texas. Of 8 species studied, all except Engelmann pricklypear suffered mortalities of at least $49 \%$ by the fourth year after burning. Mortality of some species was a direct effect of fire while fire-induced interactions with insects, rodents, and disease caused the mortality of other species to increase for several years after fire.

Mortality of brownspine pricklypear was $20 \%$ at the end of the first year and increased to $70 \%$ by the end of the fourth year.
Mortality increased at the same rate as natural mortality after the fourth year. At the end of the first year, percent brownspine pricklypear mortality caused by fire decreased as the size of the plant increased. However, by the end of the third year after the burn, there were no significant differences in the mortality of the different size classes of brownspine pricklypear.

Walkingstick cholla were more directly affected by fire than brownspine pricklypear. Mortality was $40 \%$ at the end of the first year and increased to $57 \%$ by 4 years after burning. Cholla less than $0.6 \mathrm{~m}$ tall were much more severely affected than the taller plants. After 3 years the mortality of short and tall plants was 73 and $27 \%$, respectively.

Mortality of tasajillo was $65 \%$ at the end of the first year and increased at the same rate as the control plants after the first year. Many plants were killed directly by fire and failed to resprout. No differences were observed in the mortality of the different size classes of tasajillo, but most were less than $0.6 \mathrm{~m}$ tall. Tasajillo was the most drought sensitive of the cactus species studied.

Mortality of Echinocactus texensis, Mammillaria gumitera, and Echinocereus reichenbachii at the end of 3 years was 44, 73 , and $94 \%$, respectively. The interaction of other factors with fire caused mortality of these cacti to increase over this period. Star cactus, however, was killed directly by fire. All plants were dead at the end of the first year after burning.

Engelmann pricklypear was resistant to most grass fires unless there were fine fuel accumulations greater than 6,000 $\mathrm{kg} / \mathrm{ha}$. The lack of fuel beneath the canopy and the tall growth form resulted in only the outer pads being damaged. The size of the plant was reduced but most survived the fire.

\section{Literature Cited}

Bement, R.E. 1968. Plains pricklypear: relation to grazing intensity and blue grama yield on Central Great Plains. J. Range Manage. 21:83-86.

Cable, D.R. 1967. Fire effects on semi-desert grasses and shrubs. J. Range Manage. 20:170-176.

Cook, C.W. 1942. Insects and weather as they influence growth of cactus on the Central Great Plains. Fcology 23:209-214.

Dwyer, D.D., and R.D. Pieper. 1967. Fire effects on blue grama-pinyonjuniper rangeland in New Mexico. J. Range Manage. 20:359-362.

Glendening, G.E. 1952. Some quantitative data on the increase of mesquite and cactus on a desert grassland range in southern Arizona. Ecology 33:319-328.

Heirman, A.L., and H.A. W right. 1973. Fire in medium fuels of West Texas. J. Range Manage. 26:331-335.

Houston, W.R. 1963. Plains pricklypear, weather, and grazing in the Northern Great Plains. Ecology 44:569-574.

Humphrey, R.R. 1958. The desert grassland, a history of vegetational change and an analysis of causes. Bot. Rev. 24:193-252.

Humphrey, R.R., and A.C. Everson. 1951. Effect of fire on a mixed grassshrub range in southern Arizona. J. Range Manage. 4:264-266.

Martin, S.C., J.L. Thames, and E.B. Fish. 1974. Changes in cactus numbers and herbage production after chaining and mesquite control. Prog. Agr. in Ariz. 26:3-6.

Rea, K.H., and R.D. Pieper. 1973. Interference between cholla cactus (Opuntia imbricata) (Haw) D.C.) and herbaceous range vegetation. New Mexico Agr. Exp. Sta. Res. Pap. 244. 7 p.

Reynolds, H.G., and J.W. Bohning. 1956. Effects of burning on a desert grass-shrub range in southern Arizona. Ecology 37:769-776.

Wright, H.A. 1972. Fire as a tool to manage tobosa grasslands. Proc. Tall Timbers Fire Ecol. Conf. 12:153-167. 